\title{
THE RELATIONS BETWEEN PHONOTACTICS AND SPEECH RHYTHM IN CZECH
}

\author{
ELIŠKA CHURAŇOVÁ
}

\begin{abstract}
The main objective of this study is to explore the relationships between the phonotactic structure of the Czech stress-group and rhythm of speech. Three most frequent consonantal-vocalic (CV) structures of Czech two-syllable stress-groups were selected for the purpose of this study: CVCV, CVCCV, and CCVCV. In an auditory experiment, which contained the mutual comparison of stress-groups or the comparison of a stress-group and a low-frequency shadow of a stress-group, the respondents established how similar the rhythmic pattern of each couple of stress-groups sounded.

The results indicate that the position of a consonantal cluster within the stress-group is the strongest phonotactic factor in perception of the rhythmic similarity. The number of consonants within a consonantal cluster and the presence of a long vowel in both stress-groups are considered weaker factors for perceiving the rhythmic similarity by the respondents. Possibilities for a follow-up research are proposed for the factors that did not reach statistical significance, i.e., the difference in sonority or voicing of consonants.
\end{abstract}

Key words: speech rhythm, stress-group, phonotactics, consonantal-vocalic structure, Czech

\section{Introduction}

All types of natural rhythmic behaviour show one essential characteristic, which is periodical repetition of certain patterns. These patterns consist of alternating of contrasts which are perceived as regular by the listeners. Rhythmic processes are generally easier and more stable than non-rhythmic and, therefore, they are also more eligible. The concept of stability of rhythmical actions was explored, for instance, on a synchronization of movements with metronome pulses: The experiments revealed that from a certain frequency of clicks, the anti-phase synchronization changed to in-phase (Kelso, 1995; Repp, 2005). The importance of the rhythmical events is shown even on the brain processing level (Grossberg, 2003).

Rhythmic behaviour is observed in many areas of nature. The manifestations of rhythm are embodied in the physiology of living creatures: the heartbeat, breathing, chewing, etc. Human speech is also one of the types of behaviour in which rhythmic 
aspects take place. The contrasts creating the impression of a regular rhythm are lower-level alternations such as of consonants and vowels, and higher-level alternations like stressed and non-stressed syllables.

The assumption that speech rhythm is related to the phonological structure of a given language appeared in the middle of the 20th century. Languages were classified into two (and later in three) groups according to their rhythmical characteristics (Pike, 1945; Abercrombie, 1967). In the so-called "stress-timed" languages the intervals between stresses and in "syllable-timed" the intervals between nuclei of the syllables were assumed to be equal in duration. It was expected that the latter languages, in contrast to the former, allowed for complex consonant clusters and tended to reduce vowels in unstressed positions (Dauer, 1983). This idea reassumed in many studies trying to confirm its conclusions through measuring consonantal and vocalic intervals in both classes of languages (e.g., Grabe \& Low, 2002; Ramus et al., 1999). Despite all the effort, the languages could not be divided in the above mentioned groups unambiguously. Some languages, like Czech, had characteristics of both categories to various extents (Dankovičová \& Dellwo, 2007). It is possible that these rhythmical features of languages create a continuum rather than separate groups. The weak point of the studies measuring duration of speech intervals is that these measures said nothing about the nature of rhythm itself. In the research of the rhythm of speech it is necessary that the listener is taken into account. Rhythm as such rests in the impression of isochrony (Lehiste, 1977, 1979), not in the objective equality of the intervals between contrasting events.

Nevertheless, the fact that the interval-measuring models seem unsubstantiated does not imply that consonantal-vocalic structure has no meaning in perception of rhythm. Šturm \& Volín (2016) proved that number and type of consonants in a consonantal cluster had some influence on perception of rhythm in Czech, but the exact relationship between rhythm of speech and phonology of the Czech language remains unresolved.

The carrier of rhythm - the smallest entity, on which speech rhythm manifests itself is presumably the stress-group, in Czech with fixed stress on the first syllable. Within this Western Slavonic language many types of the consonantal-vocalic (CV) structure of stress-groups exist (CV, CCV, CVCV, CCVC etc.). In Czech, the most frequent phonotactic patterns in stress-groups are CVCV (e.g., [bude]), CVCCV (e.g., [nezna:]), CVCVCV (e.g., [bohati:]), CCVCV (e.g., [stoji:]) and CVCVC (e.g., [potok]) (Churaňová, 2013). The aim of this study is to explore, whether these different phonotactic structures carry also distinct rhythmical patterns from the viewpoint of speech perception.

\section{Method}

\subsection{Material}

Fourteen texts of radio news broadcasts were selected for the purposes of the main experiment. They were read by professional native speakers of standard Czech ( 7 male and 7 female), without any dialect or slang features. The recordings were taken from the Prague Phonetic Corpus (Skarnitzl, 2010). Twelve of the recordings were used in previous study of the current author (Churaňová, 2013); two recordings were added to that 
material. All recordings were subsequently processed in the programme Praat (Boersma \& Weenink, 2018). The individual texts ranged between 234 and 603 stress-groups; the total sample consisted of 6216 stress-groups.

The duration of the material was 51.85 minutes in total. The recordings were divided into breath-groups, and TextGrid objects were accordingly created for annotation. Individual breath-groups were then divided into phones and words using the Prague Labeller algorithm (Pollák et al., 2007). Word boundaries were marked automatically, stress-groups were segmented manually (see Churaňová, 2012: 81 for further details). It was also necessary to correct all transcription errors caused by automatic annotation. All temporal and phonological data required (e.g., the duration of each stress-group and phone, the consonants and vowels in each stress-group) were gained by using an ad-hoc Praat script.

The analysis of the material revealed that the most frequent consonantal-vocalic patterns of stress-groups are CVCV (6.7\% from all the stress-groups), CVCCV (5.3\%), CVCVCV (4.4\%), CCVCV (4\%), and CVCVC (3.5\%). These results agree with the findings of Churaňová $(2012,2013)$. Since two-syllable stress-groups are typical for the Czech language, three most frequent two-syllable stress-groups (CVCV, CVCCV, CCVCV) were selected for the present experiment as possible items in the auditory perception test.

332 different types of stress-groups respecting the three consonantal-vocalic patterns were found in the material. The candidates for items in the auditory experiment were estimated with regard to balanced frequency of the word(s) constituting the stress-groups with certain phonotactic patterns. For the final candidates only the correctly pronounced stress groups with duration limited by \pm 1 standard deviation from the average duration of all stress-groups with the same vocalic quantity were selected. The stress-groups with neutral intonation were preferred.

32 phonotactic patterns (with voicing/sonority characteristics of each consonant considered) which met the above-mentioned conditions were selected for the auditory experiment. The patterns were divided into pairs according to a certain phonological or phonotactic characteristic which distinguished one pattern from the other (e.g., a pattern consisting of a voiced obstruent, short vowel, voiceless obstruent and a short vowel differs from its counterpart which consisted of a voiceless obstruent, short vowel, voiceless obstruent and a short vowel only in voicing of consonants). The pairs established four groups according to the characteristic in which the patterns in the pair differed from each other: voicing of obstruents, number of segments in a consonant cluster, position of a consonant cluster and sonority of consonants.

\subsection{Experimental design}

An item in the auditory perception test contained the comparison of two naturally spoken two-syllable stress-groups or the comparison of a naturally spoken stress-group and a low-frequency shadow of a stress-group. The low-frequency shadow of a stressgroup was obtained using a $400 \mathrm{~Hz}$ low-pass filter. This method was used to allow the listener to abstract from the segmental content of the words, and focus only on assumed rhythmic factors. The intensity of filtered items was increased by $5 \mathrm{~dB}$ to achieve perceptual comparability - because of the range of the hearing field, the items with higher 
frequencies are perceived as louder (Palková, 1994: 95-96). Some items, including both fully pronounced stress-groups and low-frequency shadows, were duplicated and manually smoothed using PSOLA (Pitch Synchronous Overlap and Add) technique, but this manipulation was required not to interfere with the impression of naturalness of speech. Items with smoothed intonation were added to eventually verify previously discovered findings that the variable or higher $F 0$ contributes to the perception of sound duration as longer than duration of the same sound with balanced fundamental frequency (Donovan \& Darwin, 1979; Brigner, 1988; Cumming, 2011; Šimko et al., 2015; Dawson et al., 2017).

Within one item, a silent pause of $750 \mathrm{~ms}$ was inserted between the stress-groups or a stress-group and the low-frequency shadow of a stress-group; a second pause lasting 1.5 seconds was added after the second stress-group or the shadow of a stress-group followed by a desensitisation sound and a silent pause $(1.5 \mathrm{~s})$. One test item lasted about 7 seconds.

A total of 210 items were pseudo-randomly sorted three times for three variants of the auditory perception test and then divided into three blocks of 70 items. The tests, together with the forms, were passed to 40 respondents, native speakers of Czech. The listeners then estimated on a five-point scale if the sounds in each item were rhythmically almost identical $(=1)$, rather similar $(=2)$, neither similar nor different $(=3)$, rather different $(=4)$, completely different $(=5)$.

\section{Results}

\subsection{Features of the experimental design}

Some of the items contained a stress-group and its own low-frequency shadow (see Section 2.2). These items were included in the test to give the respondents a reference point of rhythmic similarity. Since these items were specific (identical rhythm and speaker), all the general analyses in this chapter were performed both on the evaluation of the entire set of items and on the evaluation of the set of items that did not contain rhythmically identical stress-groups within an item.

There was a significant effect of the presence of identical stress-groups within an item (t-test: $t(221)=11.9 ; p<0.001)$. While evaluations of items that contained different stress-groups (either in full form or as a low-frequency shadow), they were around the average of 2.88, the rating of rhythmically identical items was averaging at 1.64.

Another factor in the item evaluation was the presence of a low-frequency shadow. One item could contain either two different stress-groups (e.g., [bilı] and [bude]), or one stress-group and one low-frequency shadow of another or the same stress-group (e.g., the stress-group [mezI] and the shadow of the stress-group [nImI]). T-tests showed that listeners perceived the items with a low-frequency shadow as more similar than the others. However, this relationship was only reflected in the entire set of items: $(t(221)=-2.36$; $p<0.05)$. The question is whether rhythm perception was influenced by the presence or absence of segmental content of the second stress-group, or by a general evaluation of identical stress-groups within an item as significantly more rhythmically similar than others. 


\subsection{Phonotactic features}

The results of t-tests of the items, which varied only by the number of consonants, showed a statistically significant effect of the presence vs. absence of a consonant cluster on the perception of rhythmic similarity. Stress-groups with a different number of consonants in a cluster within one item (e.g., CVCV and CCVCV - [fa:ze] and [sta:le]) were rated as rhythmically less similar than the stress-groups in items that did not include this difference. The significance was more robust when the entire set of items was analysed, $t(221)=-2.56 ; p<0.05$; in the case of omission of the items containing identical stress-groups only an insignificant trend of a similar direction was visible: $t(182)=-0.5$; $p \doteq 0.617$.

(l) All items

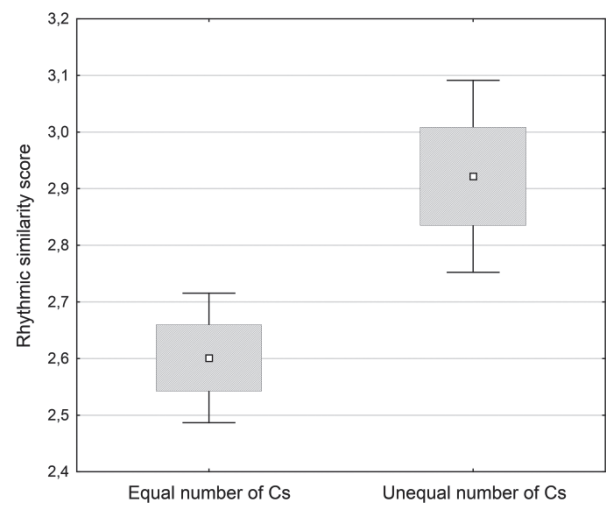

(II) Without identical stress-groups

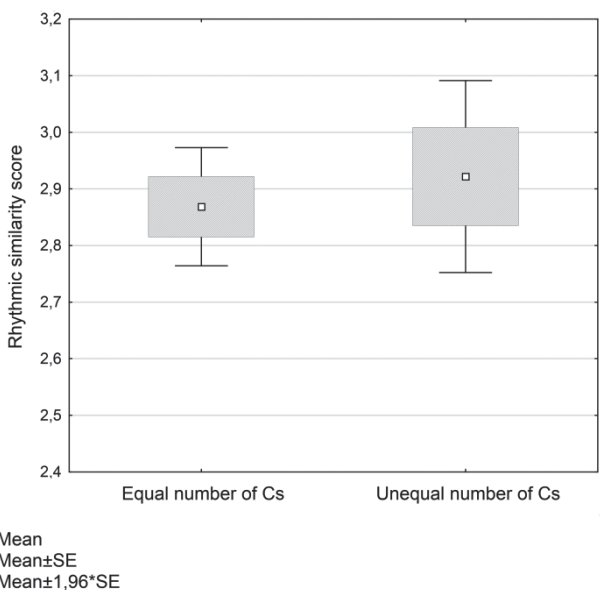

Figure 1 (I, II). A box plot of the influence of the difference in the number of consonants in the consonant cluster on the average evaluation of items. Figure I includes all data; Figure II excludes the items with rhythmically identical stress-groups. $\mathrm{SE}=$ standard error; rhythmic similarity score on y axis: $1=$ very similar, 5 = very different.

The items consisting of stress-groups with different position of a consonant cluster (e.g., CVCCV and CCVCV - [volbi] and [vjeli]) were rated as less rhythmically similar than the items in which this difference did not appear. This effect was evident both in the analysis of all items $(t(221)=-5.96, p<0.001)$ and in the analysis of the set of items that did not include items contained a stress-group with its own low-frequency shadow: $t(182)=-4.54 ; p<0.001$. Compared to the previous variable (the number of consonants in the consonant cluster), the effect of the consonant cluster position was clearly stronger.

Another feature with the presumed influence on the perception of rhythmic similarity of stress-groups was the presence of a long vowel in the compared stress-groups. If there was a long vowel in one item, it was always in the same syllable in both stress-groups compared (e.g., [sta:tI] and [sve:ho] with a long vowel in the first syllable or [bude] and [nımI] with all vowels short). If a long vowel was in just one of the stress-groups, it would 
(I) All items

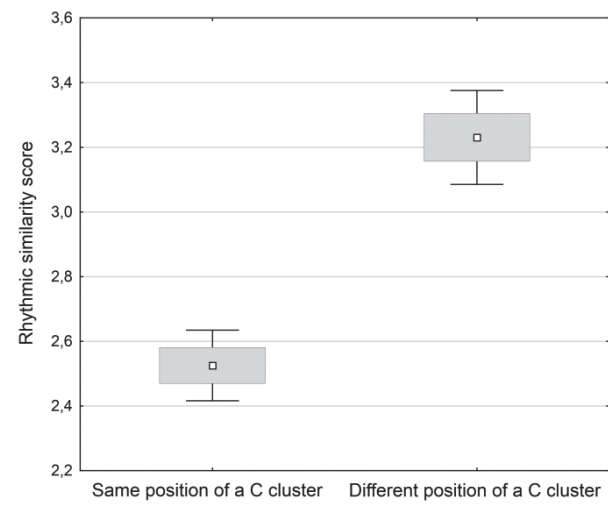

(II) Without identical stress-groups

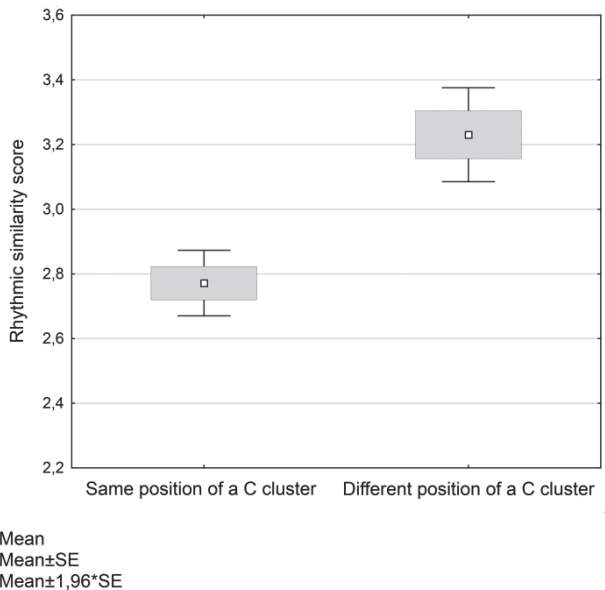

Figure 2 (I, II). A box plot of the influence of the difference in the position of a consonant cluster on the average evaluation of items. Figure I includes all data; Figure II excludes the items with rhythmically identical stress-groups.

(I) All items

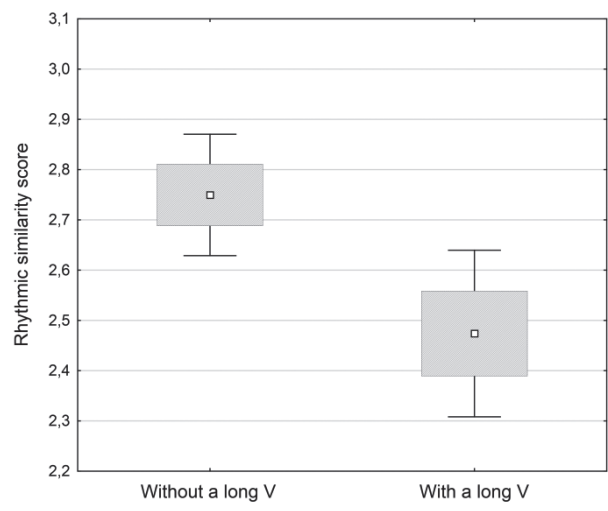

(II) Without identical stress-groups

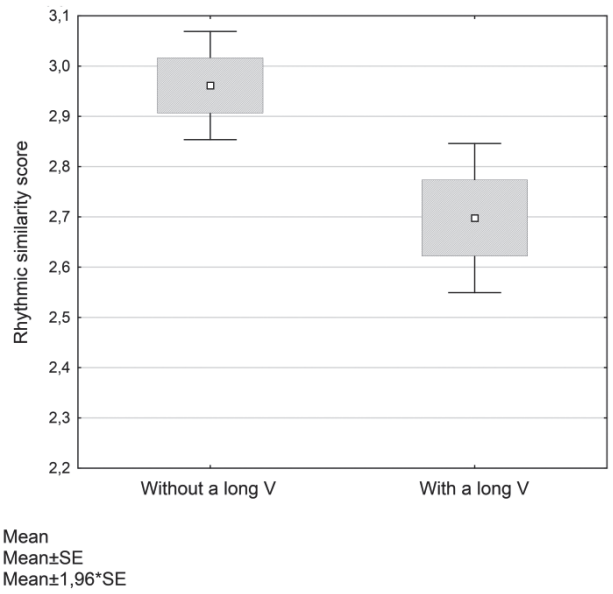

Figure 3 (I, II). A box plot of the influence of the presence of the long vowel in both stress-groups within one item on the average evaluation of items. Figure I includes all data; Figure II excludes the items with rhythmically identical stress-groups.

be difficult to trace another influence on the perception of the speech rhythm than the difference in the presence of a long vowel: the listener's attention would be fixed to the difference in the length of the vowel, and subtle effects on speech rhythm perception may therefore be suppressed.

According to the result of the t-test, stress-groups containing only short vowels were evaluated by listeners as less rhythmically similar than those with long vowels. This find- 
(I) All items

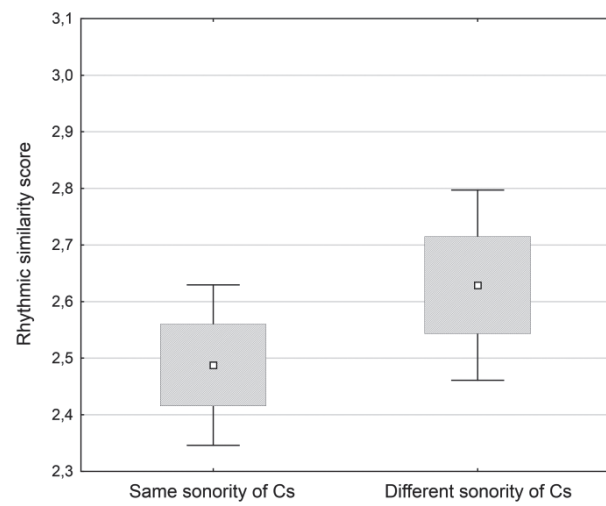

(II) Without identical stress-groups

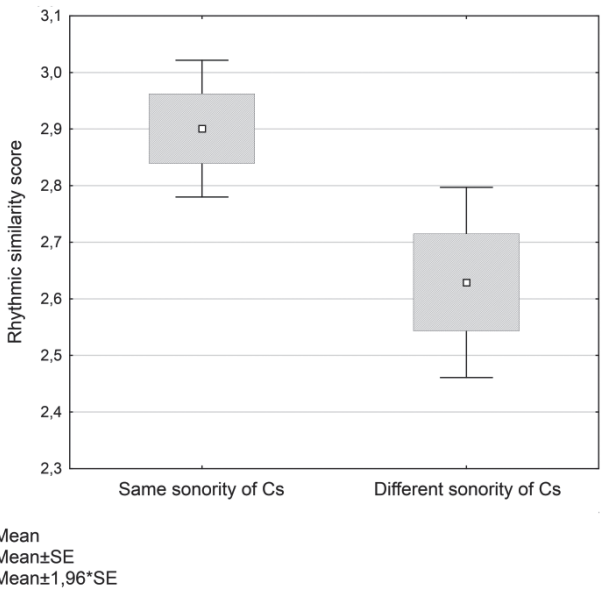

Figure 4 (I, II). A box plot of the influence of the difference in the sonority of voiced consonants on the average evaluation of items. Figure I includes all data; Figure II excludes the items with rhythmically identical stress-groups.

ing was confirmed both in the analysis of all items $(t(221)=-2.55 ; p<0.05)$ and for the set of items without those containing identical stress-groups: $t(182)=-2.72 ; p<0.01$.

The analysis of the effect of the difference in sonority of consonants on the entire set of items showed an inconclusive trend when items containing consonants of different sonority (voiced obstruents and sonorants, e.g., [zboru] and [vjeli]) were evaluated less rhythmically similar than the other items: $t(173)=-1.17 ; p \doteq 0.244$. In the analysis that did not contain items with identical stress-groups, a reverse trend appeared - the items differing in sonority of consonants were rated rhythmically less different than others: $t(134)=2.64 ; p<0.01$.

This result may appear surprising, but considering the design of the experiment, the explanation is quite simple: after omitting the items with identical stress-groups, only items with distinctions in other features remained, some of which may be considered stronger than subtle differences in sonority of consonants (e.g., the number of consonants in a cluster, the position of a consonant cluster). To examine the effect of the difference in sonority, an experiment would be required focused specifically on this feature.

The analysis of the perception of rhythmic similarity also did not show any significant effect of the distinct voicing characteristic of obstruents within a pair of stress-groups in

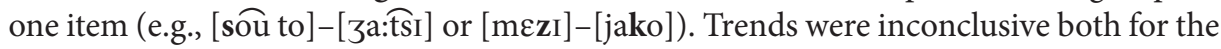
analysis of all items $(t(221)=1.31 ; p \doteq 0.192)$, and for the analysis excluding items with identical stress-groups $(t(182)=-0.88 ; p \doteq 0.381)$. However, a clear conclusion should be drawn from studies focusing exclusively on this feature.

It is worth noting that the phonological voicing feature may be indicated by factors other than the presence of the fundamental frequency. For paired consonants, the duration of the voiceless phones is longer than the duration of their voiced counterparts; some languages (e.g., English) use temporal compensations: if a voiced consonant fol- 
lows a vowel, the duration of the vowel is longer than the duration of a vowel preceding a voiceless consonant (Kent \& Read, 2002). Although the influence of temporal compensations in Czech has not been systematically investigated, the results of Borovičková \& Maláč (1967) and Machač (2006) suggested some tendencies in a similar direction. The end part of a vowel preceding a consonant appears to be a stronger clue in determining phonological voicing feature (e.g., Hogan \& Rozsypal, 1980). Speakers may indicate voicing by the presence of a fundamental frequency during the occlusion, by duration of the occlusion, by intensity of the release burst or aspiration (as in English), but also by the frequency of the fundamental tone and the first formant: The results of Hogan \& Rozsypal (1980) or Castleman \& Diehl (1996) showed that the fundamental frequency and the first formant of the vowel-consonant divide were lower if the vowel was followed by a voiced stop, as opposed to the case when the vowel preceded a voiceless stop. All these features can be perceived and used by the listener whenever it is needed, but it is also possible that the individual features contributing to the perception of phonological voicing form a hierarchy in which temporal aspects are perceived only if other clues are absent or ambiguous (Kent \& Read, 2002).

\subsection{Suprasegmental and biological factors}

The stress-groups in the perceptual test items should not contain any significant intonation differences, so that the melody changes would not interfere with the evaluation of the rhythmic similarity. However, some of the items were included in the test with the original intonation pattern, while others with $F 0$ smoothed. T-tests did not reveal any evidence of the influence of smoothed or original intonation on the perception of stress-groups as rhythmically similar. The analysis performed on all items showed only the marginal significance of the variable $(t(221)=1.91 ; p \doteq 0.057)$, when smoothed items were on average rated rhythmically more similar than others. In addition, a set of items excluding items with identical stress-groups was also analysed $(t(182)=1.51 ; p \doteq 0.133)$, as well as only the items containing smoothed intonation along with their original counterparts, again with and without the items which included identical stress-groups $(t(52)$ $=-0.23 ; p \doteq 0.822 ; t(38)=0.01 ; p \doteq 0.99$ respectively).

Another feature examined was the possible influence of different sexes of the speakers within one item. A significant difference only showed in the analysis of the full set of items: $t(221)=3.14 ; p<0.01$; the stress-groups within items in which the sexes of the speakers matched were rated more rhythmically similar. A trend of the same direction emerged in the analysis without the items containing identical stress-groups, but it was statistically insignificant: $t(182)=0.16 ; p \doteq 0.876$. It is therefore possible to conclude that the perception of rhythmic similarity was influenced by the individuality of the speaker rather than the gender. 
(I) All items

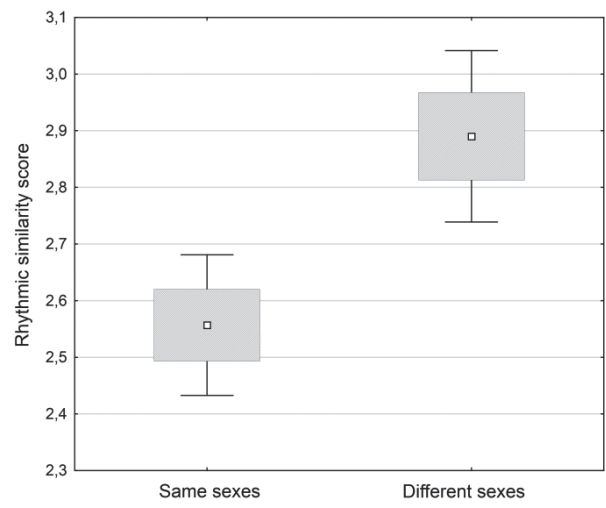

(II) Without identical stress-groups

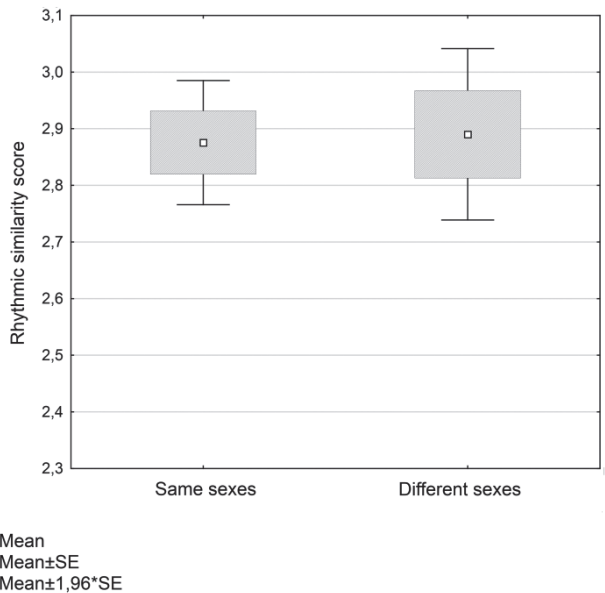

Figure 5 (I, II). A box plot of the influence of the difference in the sexes of the speakers within one item on the average evaluation of items. Figure I includes all data; Figure II excludes the items with rhythmically identical stress-groups.

Table 1. Comparison of the strength of individual influences on the perception of rhythmic similarity by comparison of the size of the test criterion $t$. Statistically significant results are bold.

\begin{tabular}{lcc}
\hline \multicolumn{1}{c}{ feature } & $\boldsymbol{t}$ (all items) & $\begin{array}{c}\boldsymbol{t} \text { (without items containing } \\
\text { identical stress-groups) }\end{array}$ \\
\hline match of the low-frequency shadow & $\mathbf{1 1 . 9}$ & \\
presence of the low-frequency shadow & $-\mathbf{2 . 3 6}$ & $\mathbf{1 . 6 8}$ \\
number of consonants in the cluster & $-\mathbf{2 . 5 6}$ & 0.5 \\
position of the consonant cluster & $-\mathbf{5 . 9 6}$ & $-\mathbf{4 . 5 4}$ \\
presence of a long vowel & $-\mathbf{2 . 5 5}$ & $-\mathbf{2 . 7 2}$ \\
difference in the sex of the speakers & $\mathbf{3 . 1 4}$ & 0.16 \\
difference in sonority of voiced consonants & -1.17 & $\mathbf{2 . 6 4}$ \\
difference in voicing of obstruents & 1.31 & -0.88 \\
smoothing of $F 0$ & 1.91 & 1.51 \\
\hline
\end{tabular}

\section{Discussion}

The main objective of the research was to find out the relations between the phonotactic structure of the Czech stress-group and the perceived rhythmicity of the speech unit. Since rhythm is a phenomenon that has its basis in listener's perception (Lehiste, 1977, 1979; Morton et al., 1976; Fletcher, 2010), an auditory assessment experiment was designed to establish this relationship. Šturm \& Volín (2016) showed that the phonotactic 
structure of the syllable played a significant role in perceiving the rhythm of Czech, and the experiment in the present study was to determine the degree of the influence of the individual phonotactic features on perception of speech rhythm.

The results showed that from the observed phonotactic factors the position of the consonant cluster in the stress-group had the strongest influence on evaluating rhythmic similarity. If the stress-groups within the item differed in this characteristic (i.e., the comparison of the stress-groups with the consonantal-vocalic patterns CCVCV and CVCCV), they were consistently evaluated by the listeners as rhythmically rather dissimilar. A slightly less strong but still relatively robust factor of speech rhythm perception was also the number of consonants in a consonant cluster - the stress-groups corresponding to the CVCV pattern were perceived by the listeners as rhythmically different from CCVCV or CVCCV units. Another important feature in evaluating rhythmic similarity was the quantity of a vowel. The respondents considered items in which a long vowel appeared in the same syllable in both stress-groups rhythmically more similar than the stress-groups with all vowels short. This trend also reached statistical significance in the evaluation of the experiment.

Although some factors proved to be almost or totally insignificant, it is impossible to state unequivocally that they do not participate in the perception of rhythmic similarity. As mentioned above, the difference in sonority of voiced consonants and in voicing of obstruents can be considered as more subtle a feature in the phonotactic structure of stress-groups, and if the significance of these contrasts is tested against items that contain differences in more robust factors (such as the position of a consonant cluster within a stress-group), the influence of the difference only in sonority or voicing of the consonants will not prove to be relevant. Whether factors such as contrast of voicing or sonority really do not participate in the perception of speech rhythm can be verified in future research focused solely on these two features. Such an experiment would include the pairs of stress-groups corresponding to the most common consonantal-vocalic patterns, which would differ either in voicing or in the sonority of consonants.

\section{Conclusion}

In terms of the phonotactic factors, the position of a consonant cluster had the strongest influence on the perception of rhythmic similarity of Czech stress-groups. The results showed that the number of consonants in each stress-group and the presence of a long vowel also contributed to the evaluation of stress-groups as rhythmically similar or different. The features as sonority of consonants and voicing of obstruents had only minimal or inconclusive effect on the perception of the rhythmic similarity of the stress-groups, but it is not possible to state without further examination that these are redundant for the perception of the speech rhythm. To capture the possible influence of these factors, a similar experiment would be required, this time only focused on the above-mentioned features. 


\section{ACKNOWLEDGEMENTS}

The author would like to express her thanks to doc. PhDr. Jan Volín, Ph.D., the supervisor of her $\mathrm{PhD}$ thesis, from which this study arose. Thanks are also due to the 40 listeners who participated in the auditory perception experiment.

\section{REFERENCES}

Abercrombie, D. (1967). Elements of general phonetics. Edinburgh: Edinburgh University Press.

Boersma, P. \& Weenink, D. (2018). Praat: doing phonetics by computer [computer program], version 6.0.30. Retrieved from http://www.praat.org.

Borovičková, B. \& Maláč, M. (1967). The Spectral Analysis of Czech Sound Combinations. Prague: Academia.

Brigner, W. L. (1988). Perceived duration as a function of pitch. Perceptual and Motor Skills, 67, 301-302.

Castleman, W. A. \& Diehl, R. L. (1996). Effects of fundamental frequency on medial and final [voice] judgments. Journal of Phonetics, 24(4), 383-398.

Cumming, R. (2011). The effect of dynamic fundamental frequency on the perception of duration. Journal of Phonetics, 39, 375-387.

Dankovičová, J. \& Dellwo, V. (2007). Czech speech rhythm and the rhythm class hypothesis. In: Proceedings of the XVIth ICPhS, 1241-1244. Saarbrücken: Organizing Committee.

Dauer, R. (1983). Stress-timing and syllable-timing reanalyzed. Journal of the International Phonetic Association, 11, 51-62.

Dawson, C., Aalto, D., Šimko, J. \& Vainio, M. (2017). The influence of fundamental frequency on perceived duration in spectrally comparable sounds. PeerJ, 5.

Donovan, A. \& Darwin, C. J. (1979). The perceived rhythm of speech. In: Fischer-Jørgensen, E. et al. (Eds.), Proceedings of IXth ICPhS, 268-274. Copenhagen: University of Copenhagen.

Fletcher, J. (2010). The Prosody of Speech: Timing and Rhythm. In: Hardcastle, W., Laver, J. \& Gibbon, F. (Eds.), The Handbook of Phonetic Sciences, 523-602. United Kingdom: Wiley-Blackwell Publishing.

Grabe, E. \& Low, E. L. (2002). Durational variability in speech and the rhythm class hypothesis. In: Warner, N. \& Gussenhoven, C. (Eds.), Papers in laboratory phonology 7, 515-546. Berlin: Mouton de Gruyter.

Grossberg, S. (2003). Resonant neural dynamics of speech perception. Journal of Phonetics, 31(3-4), $423-445$.

Hogan, J. T. \& Rozsypal, A. J. (1980). Evaluation of vowel duration as a cue for the voicing distinction in the following word-final consonant. Journal of the Acoustical Society of America, 67, 1764-1771.

Churaňová, E. (2012). Fonotaktická osnova českého slova a mluvního taktu. Master's thesis. Prague: Charles University.

Churaňová, E. (2013). The consonantal-vocalic structure of the Czech word and stress group. AUC Philologica 1/2014, Phonetica Pragensia XIII, 79-90.

Kelso, J. A. (1995). Dynamic Patterns: The Self-Organization of Brain and Behavior. Cambridge: MIT Press.

Kent, R. D. \& Read, C. (2002). The acoustic analysis of speech. Australia: Singular/Thomson Learning.

Lehiste, I. (1977). Isochrony reconsidered. Journal of Phonetics, 5, 253-263.

Lehiste, I. (1979). Temporal relations within speech units. In: Fischer-Jørgensen, E. et al. (Eds.). Proceedings of IXth ICPhS, 241-244. Copenhagen: University of Copenhagen.

Machač, P. (2006). Temporální a spektrální struktura českých explozív. PhD thesis. Prague: Charles University.

Morton, J., Marcus, M. \& Frankish, C. (1976). Perceptual centres (P-centres). Psychological Review, 83, 405-408.

Palková, Z. (1994). Fonetika a fonologie češtiny. Prague: Karolinum. 
Pike, K. L. (1945). The intonation of American English. University of Michigan Press: Ann Arbor.

Pollák, P., Volín, J. \& Skarnitzl, R. (2007). HMM-Based Phonetic Segmentation in Praat Environment. In: Proceedings of the XIIth International Conference "Speech and computer - SPECOM 2007", 537-541.

Ramus, F., Nespor, M. \& Mehler, J. (1999). Correlates of linguistic rhythm in the speech signal. Cognition, 73(3), 265-292.

Repp, B. H. (2005). Sensorimotor synchronization: A review of the tapping literature. Psychonomic Bulletin \& Review, 12(6), 969-992.

Skarnitzl, R. (2010). Prague Phonetic Corpus: status report. AUC Philologica 1/2009, Phonetica Pragensia XII, 65-67.

Šimko, J., Aalto, D., Lippus, P., Włodarczak, M. \& Vainio, M. (2015). Pitch, perceived duration and auditory biases: comparison among languages. In: Proceedings of the 18th ICPhS. Glasgow: University of Glasgow.

Šturm, P. \& Volín, J. (2016). P-centres in natural disyllabic Czech words in a large-scale speech-metronome synchronization experiment. Journal of Phonetics, 55, 38-52.

\title{
RESUMÉ
}

Tato studie si klade za cíl prozkoumat vztahy mezi fonotaktickou stavbou českého mluvního taktu a řečovým rytmem. Pro účely této práce byly vybrány takty, jež odpovídaly třem nejčastějším dvouslabičným konsonanticko-vokalickým (CV) vzorcům v češtině: CVCV, CCVCV a CVCCV. V percepčním experimentu, který zahrnoval srovnávání dvou plně proslovených mluvních taktů nebo taktu a nízkofrekvenčního obrazu jiného či stejného taktu, posluchači určovali, nakolik jsou si takty různých i stejných vzorců rytmicky podobné.

Výsledky ukázaly, že nejsilnější vliv na vnímání rytmické podobnosti má z fonotaktických faktorů pozice souhláskového shluku v mluvním taktu. O něco méně silnými faktory pro percepci řečového rytmu byly počet souhlásek $\mathrm{v}$ konsonantickém shluku a př́tomnost dlouhého vokálu v obou porovnávaných taktech. Pro subtilnější rysy, jejichž význam pro percepci rytmické podobnosti prokázán nebyl (např. rozdíl v sonoritě znělých souhlásek či znělosti obstruentů), byly navrženy možnosti dalšího zkoumání.

\author{
Eliška Churaňová \\ Institute of Phonetics \\ Faculty of Arts, Charles University \\ Prague, Czech Republic \\ E-mail:eliska.churanova@gmail.com
}

